\title{
VROEË ADOLESSENTE SE PERSEPSIES VAN HULLE PRIMÊRE VERSORGERS SE BETROKKENHEID BY DIE SKOOLGEMEENSKAP IN 'N HOË-RISIKO GEMEENSKAP
}

\begin{abstract}
Author:
Cronjé-Malan, $\mathrm{L}^{1}$

Dr. Van Schalkwyk, L ${ }^{1}$
\end{abstract}

\section{Affiliation:}

${ }^{1}$ Sentrum vir Kinder, Jeug en Familiestudies, Noordwes

Universiteit

\section{Correspondence to:} Cronjé-Malan, L

Email:

cronje.leandra6@gmail.

\section{Postal address:}

Postnet Suite 259,

Privaatsak X22,

Tygervallei,

7536

\section{Correspondence to:}

Dr. Van Schalkwyk, L

Email:

20977026@nwu.ac.za

Dates:

Published: 01 Des. 2015

How to cite this article: Cronjé-Malan, L. \& Van Schalkwyk, L., 2015, 'Vroeë adolessente se persepsies van hulle primêre versorgers se betrokkenheid by die skoolgemeenskap in ' $n$ hoë-risiko gemeenskap', KOERS - Bulletin for Christian Scholarship, 80(2). Available at: http:// dx.doi.org/10.19108/ koers.80.2.2226

\section{Copyright:}

(c) 2015. The Author(s).

Published under the

Creative Commons

Atribution License.
Early adolescents' perceptions of their primary care-givers' involvement as to the school context in a high-risk community is important for their relational and personal well-being. Although school performance is of crucial importance concerning positive youth development, many South African adolescents are still part of the high incidence of repeating grades and drop-out statistics. The study was conducted within the theoretical framework of positive psychology to explore resources aimed at higher levels of well-being.

The qualitative method was used, and participants between the ages of twelve and fourteen years of age, of one school in a high-risk community, were selected.. Demographic information shows that the primary care-givers of most participants are not their biological parents.

Findings indicate that early adolescents' perceptions of family imply the providing of basic needs as a requirement for school involvement. Also, the mostly negative emotional nature of home and learning environment interactions, adds to negative patterns which are associated with a high-risk community.

This study offers an important contribution to Positive Psychology towards the understanding of early adolescents' relational well-being and its context. Recommendations include guidelines for interventions while taking into account external as well as internal factors.

Keywords: Early adolescents, primary care-givers, school community, high-risk community

Vroeë adolessente se persepsies van hul primêre versorgers se betrokkenheid by die skoolkonteks in 'n hoë-risiko gemeenskap is bepalend vir hul verhoudings- en persoonlike welstand. Alhoewel skoolprestasie van deurslaggewende belang is om positiewe jeugontwikkeling te bewerkstellig, is vele Suid-Afrikaanse adolessente steeds deel van die hoë voorkoms van herhaal-enuitvalstatistiek. Die studie is gedoen binne die teoretiese raamwerk van die positiewe sielkunde om hulpbronne te verken wat welstand kan bevorder.

Die kwalitatiewe metode is gebruik, en deelnemers tussen die ouderdomme twaalf en veertien jaar oud, verbonde aan een skool in 'n hoë-risiko gemeenskap, is gekies. Demografiese inligting toon dat die meeste deelnemers se primêre versorgers nie hul biologiese ouers is nie.

Bevindings toon dat vroeë adolessente se persepsies van familie die voorsiening van basiese behoeftes as ' $\mathrm{n}$ vereiste vir skoolbetrokkenheid behels. Die hoofsaaklik negatiewe emosionele aard van skool-en-huis interaksies dra by tot negatiewe patrone wat met ' $n$ hoë-risiko omgewing geassosieer word.

Hierdie studie lewer ' $n$ belangrike bydrae tot die Positiewe Sielkunde, aangesien waardevolle inligting verkry is sodat vroeë adolessente se verhoudingswelstand binne konteks verstaan kan word. Aanbevelings behels riglyne vir intervensies met die inagneming van eksterne asook interne faktore.

Trefwoorde: Vroeë adolessente, primêre versorgers, skoolgemeenskap, hoë-risiko gemeenskap 


\section{INLEIDING}

Mnr. Mandela, oud-president van Suid-Afrika, het mense wêreldwyd geïnspireer met sy uitgangspunt dat opvoeding die sleutel is om die wêreld ten goede te verander ("Education is the most powerful weapon which you can use to change the world"). Verskeie Suid-Afrikaanse adolessente is egter steeds deel van die hoë herhaal- en uitvalstatistiek in die land (Louw, Bayat \& Eigelaar-Meets 2011:1-74). Alhoewel verskeie navorsers meld dat skoolprestasie en akademiese sukses van deurslaggewende belang is om positiewe jeugontwikkeling te bewerkstellig (You \& Nguen 2011; Louw, Bayat \& Eigelaar-Meets 2011:1-74), blyk dit dat skoolsukses nie bloot die slaag van eksamens behels nie, maar 'n spesifieke kombinasie van faktore insluit. Een van diefundamentelefaktore is gesonde ouerbetrokkenheid by die skoolomgewing (Jodl, Micheal, Malanchuk, Eccles \& Sameroff 2001:1247-1265; Tomyn \& Cummins 2010:405-418; You \& Nguen 2011:547; Hong \& Ho 2005:32-42).

Die fokus van hierdie artikel is vroeë adolessente se persepsies van hul primêre versorgers se betrokkenheid by die skoolgemeenskap. Die positiewe benadering van die sielkunde behels gesonde funksionering en meegaande emosionele gesondheid, asook daardie kwessies wat welstand bedreig (Seligman 2011). Hierdie risiko's vir welstand noodsaak die kontekstuele verstaan van verhoudingsprosesse en positiewe groei onder negatiewe toestande ("adversity"), wat weer 'n belangrike lens bied vir wetenskaplike verkenning (Ungar 2000; Ungar, 2008:218-235). Vroeë adolessente se persoonlike welstand is ten nouste gekoppel aan kollektiewe en verhoudingswelstand (Nelson \& Prilleltensky 2010:53-60). Gesonde ontwikkeling behels die deelwees van gesinne en Suid-Afrikaanse wetgewing is verander sodat ook kinders wie se biologiese ouers ontbreek, blootgestel kan word aan die belewing van 'n ouerhuis (SASA, 1996:np). Dit beteken dat verskeie primêre versorgers wat die rol van ouers vertolk, nie noodwendig die biologiese ouers van hul kinders is nie. Die ervaring van ' $n$ gesonde huisgesin en hegte verhoudings wat sosiale kapasiteit en verhoudingskapitaal bou, is 'n onontbeerlike aspek van welstand (Louw, Van Ede \& Louw 2001; Seligman, 2011). Die ervaring van gesonde verhoudings bied 'n rykdom van sosiale hulpbronne wat alle kinders en vroeë adolessente se welstand kan beskerm en toenemend bevorder (Keyes 2007:95-108). Fredrickson (2009; 2013) meld ook dat algehele welstand bevorder word deur die belewing van gesonde verhoudings en hegte verbintenisse en dat positiewe emosies soos liefde en hoop die aktiewe bestanddele is vir volgehoue welstand. Brooks (2006:297-314) dui aan dat die daaglikse insette en betrokkenheid van primêre versorgers se liefdevolle belangstelling en gesprekke met hul vroeë adolessente, op die kort- en langtermyn 'n grootse belegging kan bied in die skool-en-leefsukses van kinders. Alhoewel dit duidelik is dat positiewe verhoudings ' $n$ integrale deel van welstand is, blyk dit dat die teenoorgestelde ook waar is, naamlik dat wanneer vroeë adolessente nie gesonde verhoudings beleef nie, hul welstand erg gestrem kan word.

Die langdurige teenwoordigheid van lae vlakke van welstand en patologie kan die groter waarskynlikheid van siektetoestande en verdere versteurings behels (Van Schalkwyk \& Wissing
2010:53). Tipiese aanduiders van die afwesigheid van welstand vir adolessente is die belewing van 'n doellose bestaan en betekenisloosheid, soos adolessente wat nie hul skoolloopbaan voltooi nie; die belewing van disfunksionele verhoudings met hul primêre versorgers; identifisering met disfunksionele ander, soos bendelede of dwelmsmouse; negatiewe emosies soos woede of frustrasie; en die belewing van hulpeloosheid (Van Schalkwyk \& Wissing 2010:53-60). Die genoemde aspekte het grootliks te make met die belewing, of nie, van verhoudings as hulpbronne van welstand.

Dit blyk dat die weelde van gesonde verhoudings méér behels as die blote blootstelling aan 'n ouerhuis-ervaring en versorging. Navorsers maan dat verhoudingswelstand nie net in die lig van interpersoonlike kontekste verstaan word nie (Felner 2006: 127); maar ook in terme van die interaktiewe en dinamiese aard van die individu wat konstant in verhouding is met ander én die omgewing (Nelson \& Prilleltensky 2010; Felner 2006; Ungar 2011). Felner (2006:126) beklemtoon die persoon-omgewing-transaksies wanneer kinders en adolessente langdurig aan armoede blootgestel word. Hierdie volgehoue belewing van voortdurende armoede beïnvloed die ontwikkelingsfases vanaf voorgeboorte tot volwassenheid (Hope \& Van der Merwe 2013:309).

Langdurige armoede word geassosieer met hoë-risiko omgewings (Felner 2006:126). Die Delft-gemeenskap in die Wes-Kaap is een van twintig hoë-risiko gemeenskappe in Suid-Afrika. Hierdie leefomgewing is ' $n$ bloudruk van hoë-risiko gemeenskappe soos swak standaarde van behuising; hoë voorkoms van misdaad soos moord, diefstal en verkragting; alkohol- en substansmisbruik; geweld, soos bendegeweld; min opsies vir naskoolse kindersorg; en gebrekkige blootstelling aan positiewe rolmodelle wat die drome en verwagtings van adolessente kan vorm (Delft-sensus 2011). Die Delftgemeenskap is ook ' $n$ tipiese voorbeeld van een van Suid-Afrika se grootste probleemkwessies, naamlik die hoë voorkoms van werkloosheid (25.6 persent, Junie 2015) waar sosiale stressors soos gesinsgeweld die impak van gesinsarmoede vergroot (Jaffee 2006:149-164). Suid-Afrika word tans geag as een van die lande met die grootste sosio-ekonomiese ongelykhede ter wêreld, en naas die toename in wettelose gedrag en korrupsie blyk dit dat die Suid-Afrikaanse bevolking grootliks hul vertroue ("trust") in die regering verloor het (Gouws, 2015). Hierdie ongelyke sosio-ekonomiese kontekste en meegaande verwikkelinge beïnvloed egter die ontwikkeling van SuidAfrikaanse kinders negatief (Guse \& Vermaak, 2011:527). Die Delft-gemeenskap huisves die "armste" mense wat byvoorbeeld nie mediese sorg kan bekostig wanneer hulle siek is nie, of, 'n vroeë dood verwag te wyte aan geweld, of die roof van hul inkomste wat verdien is deur harde werk. Volgens prof Barney Pityana is hierdie belewings die tekens van wanhoop en nie vryheid nie, terwyl vryheid en geregtigheid ("justice") juis een van die beloftes van 'n demokratiese stelsel en die Suid-Afrikaanse grondwet is. Die woorde van Pityana dui op hierdie ongerymdheid: "The irony of all this is that we are a democratic and constitutional state. We are proud that the Constitutional Court continues to uphold constitutional values of human dignity, the achievement of equality and the advancement of human rights and freedoms...". Hierdie 
absolute armoede en uiters gebrekkige fisiese en sosiale hulpbronne behels die afwesigheid van "veiligheidsnette" vir kinders. Die effek van armoede en sosio-ekonomiese agterstand op vroeë adolessente in hoë-risiko omgewings, beïnvloed die hele spektrum van hul gesondheid soos sosiale, emosionele, fisiese funksionering asook intellektuele funksionering. Naas al die genoemde faktore behels hoë-risiko omgewings ook die voorkoms van swak-presterende skole. Daar is agt-entwintig skole in die Delft-omgewing en hierdie leeromgewings het te make met besondere uitdagings vir akademiese prestasie asook gesonde sosiale funksionering (Louw, Bayat \& Eigelaar-Meets 2011:1-74). Een van die belangrikste aanduiders van swak skoolprestasie is egter die gebrek aan of onvoldoende belangstelling van ouers by hul kinders se skoolopleiding (Louw, Bayat \& Eigelaar-Meets 2011:1-74). Ungar en Teram (2000:228-252) dui aan dat stremmende verhoudingspatrone in die huis-en-skoolkonteks kan lei tot die voortsetting van negatiewe spirale van sosiale bronverlies, toenemende risikogedrag en psigologiese afwykings. Dit is ook gemeld dat hierdie verhoudings-interaksies altyd gebeur binne 'n bepaalde konteks, soos die Delft-gemeenskap as 'n hoë-risiko gemeenskap.

Hierdie navorsing is onderneem omdat daar ten spyte van die belangrikheid van ouerbetrokkenheid by skoolgemeenskappe (You \& Nguyen 2011:547), blyk dat die aktiewe deelname en betrokkenheid van primêre versorgers/ouers in die Delftgemeenskap gebrekkig is (persoonlike onderhoud met mnr Malgate, skoolhoof te Delft, Julie 2013). Studies wat handel oor onderpresterende skole in die Wes-Kaap dui aan dat die passiewe of destruktiewe betrokkenheid van primêre versorgers nie net adolessente se akademiese prestasie belemmer nie, maar ook 'n reuse uitdaging vir skole bied (Louw, Bayat \& Eigelaar-Meets 2011:1-74). Ander Suid-Afrikaanse studies het ook aangetoon dat stremmende verhoudingspatrone gekenmerk word deur wedersyde frustrasies en wantroue tussen die skool-enhuisgemeenskap (Kitching, Roos \& Ferreira 2012:39-51).

Verder is dit nodig dat alle sosiale hulpbronne en veerkragtige hantering, soos die dinamika van gesonde interaktiewe konneksies by die huis-en-skoolomgewing, verken moet word om verhoudingswelstand ("relational well-being") te bou (Nelson \& Prilleltensky 2010). Verhoudingswelstand impliseer verhoudingsdeelname en die verkenning van hierdie kosbare kragbronne - wat nie noodwendig enige finansiële hulpbronne verg nie - is van beslissende belang vir vroeë adolessente se persoonlike welstand asook die leerkonteks (Van Schalkwyk \& Wissing 2010:53-60). Verhoudingswelstand word egter gekortwiek wanneer primêre versorgers, ongeag sosioekonomiese stratifikasie, ouerbetrokkenheid hoofsaaklik verstaan as die verskaffing van leefmiddels, die beskerming teen gevare, soos bendegeweld en verkragting, eerder as die waarde van kognitief-intellektuele bystand en liefdevolle interaksie (persoonlike gesprek met laerskoolhoof te Delft, Junie 2013).

Laastens maan Khumalo, Temane en Wissing (2012:419) dat die impak van sosio-ekonomiese faktore vir welstandstudies en die rol van konteks nie buite rekening gelaat kan word nie. Ook Seligman (2011) meld dat welstand-studies wat binne die teroretiese raamwerk van Positiewe Sielkunde gedoen word, daardie buffers behoort bloot te lê teen risiko-gedrag vir gesonde ontwikkeling en aangeleerde leefkrag. Sulke navorsing omvou die verkenning van vroeë adolessente se belewings en perspektiewe ("verstehen") sodat gepaste intervensies ontwikkel kan word vir die gesonde betrokkenheid van primêre versorgers by hul kinders se skoolgemeenskappe in hoë-risiko omgewings (Van Schalkwyk \& Wissing 2013:601). Hierdie inligting, wat die waarde van kontekstuele faktore in ag neem, is broodnodig sodat negatiewe spirale wat gebroke verhoudings, ontmagtigende gemeenskappe en akkumulerende faktore behels, soos hoë uitvalstatistiek en toenemende werkloosheid, nie voortgesit word nie.

\section{METODE EN PROSEDURE}

Hierdie verkennende studie het die kwalitatiewe navorsingsmetode gebruik. Die fenomenologiese navorsingsontwerp is met vrug gebruik om die vroeë adolessente se persepsies en meegaande verhoudingsbelewenisse vas te stel (Strydom et al. 2011, 142-157).

\section{DEELNEMERS}

'n Doelgerigte steekproef is gebruik om die spesifieke inligting aangaande die fenomeen te verkry (Creswell 2007). Twaalf leerders verbonde aan 'n primêre skool in 'n hoë-risiko Suid-Afrikaanse gemeenskap het aan die navorsingstudie deelgeneem. Beide seuns en dogters is as deelnemers geselekteer. Die deelnemers was almal Afrikaanssprekende persone van kleur. Insluitende kriteria is gebruik, soos taalvaardigheid (die deelnemers moes Afrikaans magtig wees ten einde taalkwessies of gebrekkige verstaan te vermy); ouderdom (deelnemers moes tussen twaalf en veertien jaar oud wees om die vroeë adolessente-leeffase te verteenwoordig); geslag (seuns en dogters is gekies as deelnemers); graad (deelnemers moes in graad ses of sewe wees en nie vorige skoolgrade meer as twee keer herhaal het nie); verblyf (primêre versorgers moes nie onwettige plakkers wees nie, en was inwoners van die Delft-gemeenskap, wat 'n hoërisiko gemeenskap is.

\section{DEMOGRAFIESE INLIGTING}

Demografiese inligting van die deelnemers aan die studie is verkry rakende die volgende faktore: aard van primêre versorgers (biologiese ouers, of nie); ouderdom van deelnemers; skoolgraad (herhaling of nie); en familie-verteenwoordiger by skoolbyeenkomste.

\section{Demografiese inligting van deelnemers}

Al die deelnemers was tussen die ouderdomme van twaalf en veertien jaar oud. Almal is van kleur, Afrikaanssprekend en woonagtig in die hoë-risiko gemeenskap. Die meeste deelnemers se primêre versorgers was nie hul nie biologiese ouers nie. Beide manlike en vroulike deelnemers het aan die studie deelgeneem. 
TABEL 1: Demografiese inligting van deelnemers

\begin{tabular}{|c|c|c|c|}
\hline Deelnemer & $\begin{array}{l}\text { Primêre } \\
\text { versorgers }\end{array}$ & $\begin{array}{l}\text { Geslag, graad en } \\
\text { ouderdom }\end{array}$ & Spesifieke inligting van deelnemer en primêre versorger \\
\hline D1 & Vader & $\begin{array}{l}\text { Geslag: manlik } \\
\text { Graad: sewe } \\
\text { Ouderdom: veertien } \\
\text { Graad nie herhaal }\end{array}$ & $\begin{array}{l}\text { Moeder is vyf jaar gelede oorlede. Vader betaal die skoolfonds. } \\
\text { Die kind is gereeld in die moeilikheid in verband met dagga. } \\
\text { Die vader word dan gevra om die skoolhoof te besoek. }\end{array}$ \\
\hline D2 & $\begin{array}{l}\text { Ma en ma se } \\
\text { vriend }\end{array}$ & $\begin{array}{l}\text { Geslag: Vroulik } \\
\text { Graad: sewe } \\
\text { Ouderdom: veertien } \\
\text { Graad: herhaal }\end{array}$ & $\begin{array}{l}\text { Moeder se vriend ("boyfriend") is werkloos, gebruik dwelms en } \\
\text { steel van die gesin. Die moeder werk slegs } 2 \text { dae ' } n \text { week. } \\
\text { Die skoolfonds word nie betaal nie. }\end{array}$ \\
\hline D3 & Ouma en oupa & $\begin{array}{l}\text { Geslag: Vroulik } \\
\text { Graad ses } \\
\text { Ouderdom: dertien } \\
\text { Graad: herhaal }\end{array}$ & $\begin{array}{l}\text { Die ouma en oupa is beide sieklik, deelnemer help met hul } \\
\text { versorging. die versorging van hulle. Die skoolfonds word nie } \\
\text { betaal nie. }\end{array}$ \\
\hline D4 & Tante en ouma & $\begin{array}{l}\text { Geslag: Vroulik } \\
\text { Graad: ses } \\
\text { Ouderdom:Twaalf } \\
\text { Graad:nie herhaal }\end{array}$ & $\begin{array}{l}\text { Deelnemer help om die ouma te was en versorg (oor naweke). Die } \\
\text { tante is ook siek. Haar ouer broer help haar met tuiswerk en hy } \\
\text { gaan woon die skool vergaderings by namens die familie. } \\
\text { Die skoolfonds word nie betaal nie. }\end{array}$ \\
\hline D5 & Ma en ouma & $\begin{array}{l}\text { Geslag: Vroulik } \\
\text { Graad: sewe } \\
\text { Ouderdom: veertien } \\
\text { Graad: herhaal }\end{array}$ & $\begin{array}{l}\text { Die vader woon saam met sy "nuwe" gesin in Mitchelsplain. } \\
\text { Die skoolfonds word nie betaal nie. }\end{array}$ \\
\hline D6 & Ma en pa & $\begin{array}{l}\text { Geslag: vroulik } \\
\text { Graad: ses } \\
\text { Ouderdom: dertien } \\
\text { Graad herhaal }\end{array}$ & $\begin{array}{l}\text { Die moeder gaan skool toe as daar probleme is by die skool. } \\
\text { Die skoolfonds word nie betaal nie. }\end{array}$ \\
\hline D7 & $\begin{array}{l}\text { Ma en ma se } \\
\text { vriend }\end{array}$ & $\begin{array}{l}\text { Geslag: vroulik } \\
\text { Graad: ses } \\
\text { Ouderdom: dertien } \\
\text { Graad herhaal }\end{array}$ & $\begin{array}{l}\text { Die moeder gaan slegs skool toe as daar moeilikheid is by die skool } \\
\text { rakende die deelnemer. Die skoolfonds word nie betaal nie. }\end{array}$ \\
\hline D8 & Ouma & $\begin{array}{l}\text { Geslag: manlik } \\
\text { Graad : ses } \\
\text { Ouderdom: dertien } \\
\text { Graad herhaal }\end{array}$ & $\begin{array}{l}\text { Die ouma is 'n pensionaris. Hulle lewe in erge armoede. Sommige } \\
\text { dae het hulle nie kos om te eet nie. Deelnemer se ouma was al } \\
\text { skool toe, toe hy in die moelikheid was omdat hy bakklei het by die } \\
\text { skool. Hy woon by sy ouma. (Pa oorlede, ma het weggeloop). } \\
\text { Die skoolfonds word nie betaal nie. }\end{array}$ \\
\hline D9 & Ma en pa & $\begin{array}{l}\text { Geslag: manlik } \\
\text { Graad: sewe } \\
\text { Ouderdom: dertien } \\
\text { Graad nie herhaal }\end{array}$ & $\begin{array}{l}\text { Dit is 'n disfunksionele gesin. Die moeder woon wel skool- } \\
\text { vergaderings by. Die skoolfonds word betaal. }\end{array}$ \\
\hline D10 & $\begin{array}{l}\text { Stiefma, pa en } \\
\text { ouma }\end{array}$ & $\begin{array}{l}\text { Geslag: Vroulik } \\
\text { Graad: ses } \\
\text { Ouderdom: Twaalf } \\
\text { Graad: nie herhaal }\end{array}$ & $\begin{array}{l}\text { Hierdie uitgebreide gesin bestaan uit altesaam } 10 \text { mense. Die ma is } \\
\text { oorlede. Die stiefmoeder gaan skooltoe as daar moeilikheid is soos } \\
\text { wanneer die deelnemer by die skool baklei. Die skoolfonds word } \\
\text { betaal. }\end{array}$ \\
\hline
\end{tabular}




\begin{tabular}{|c|c|c|c|}
\hline Deelnemer & $\begin{array}{l}\text { Primêre } \\
\text { versorgers }\end{array}$ & $\begin{array}{l}\text { Geslag, graad en } \\
\text { ouderdom }\end{array}$ & Spesifieke inligting van deelnemer en primêre versorger \\
\hline D11 & $\mathrm{Ma}$ & $\begin{array}{l}\text { Geslag: Manlik } \\
\text { Graad: ses } \\
\text { Ouderdom: Dertien } \\
\text { Graad: nie herhaal }\end{array}$ & $\begin{array}{l}\text { Hierdie gesin beleef gesinsgeweld. Die moeder loop gereeld weg in } \\
\text { die middel van die nag, dan kom sy na weke weer terug. } \\
\text { Die deelnemer het al weggeloop van die huis af. Die vader gaan } \\
\text { skool toe as daar probleme is. Die skoolfonds word nie betaal nie. }\end{array}$ \\
\hline D12 & Ma en stiefpa & $\begin{array}{l}\text { Geslag: Manlik } \\
\text { Graad : sewe } \\
\text { Ouderdom: Dertien } \\
\text { Graad: nie herhaal }\end{array}$ & $\begin{array}{l}\text { Die moeder woon wel skool-vergaderings by. Die skoolfonds word } \\
\text { nie betaal nie. }\end{array}$ \\
\hline
\end{tabular}

\section{Demografiese inligting van die Delft-gemeenskap}

Die Delft-gemeenskap word gekenmerk deur armoede, infor-mele nedersettings, werkloosheid van primêre versorgers, gebrekkige infrastruktuur, swak-presterende skole, en vervoerprobleme.

\section{ETIESE VEREISTES EN PROSEDURE}

Toestemming is verkry vir die navorsingsprojek by die etiekkomitee van die Noordwes-Universiteit sodat die studie gedoen kon word (NWU_ooo6o-12_A1). Daar is aan die nodige etiese vereistes voldoen en skriftelike, ingeligte toestemming van die primêre versorgers en ingeligte instemming van die deelnemers is verkry. Deelname was vrywillig en objektiwiteit, vertroulikheid en naamloosheid is verseker ten einde die deelnemers te beskerm. Data is getranskribeer en op ' $n$ veilige plek bewaar. Data-insameling het plaasgevind deur die maak van collages (visuele materiaal), persoonlike onderhoude en die World Café-tegniek.

Die versamelde data is getranskribeer en die inligting is gebruik vir die data-analise. Tematiese analise soos beskryf deur Braun en Clark (2013:173) is gebruik. Die proses van bekendwording het die maak van nuwe aantekeninge ingesluit om potensiële idees vir kodering met die oog op temas te vergemaklik. Rou data is gekodeer, uittreksels uit die data is in kodes omskryf en geklassifiseer, die kodes is saamgevoeg as oorhoofse temas en opgesom in die vorm van ' $n$ tabel. Uiteindelik is die temas verfyn om die essensie van die studie weer te gee (Nieuwenhuis, in Maree 2011:111).

Vertrouenswaardigheid is bewerkstellig deur die gebruik van verskillende data-insamelingstegnieke soos collages, persoonlike onderhoude, asook verskillende metodes van analise. Kristallisasie is gebruik soos uiteengesit deur Tracy (2010:837-851) en Ellingson (2009).

\section{BEVINDINGS}

Die bevindings word vervolgens binne die konteks van positiewe sielkunde en bestaande teorieë beskryf. Die verkenning van vroeë adolessente se persepsies van hul primêre versorgers se betrokkenheid by die skool in 'n hoë-risiko gemeenskap dui op die volgende: algemene versorging van jong aoldessente as vereiste vir skoolbetrokkenheid; die negatiewe emosionele aard van huis-en-skool-interaksies; die aard van primêre versorgers se betrokkenheid by die skool; en, die rol van 'n hoë-risiko gemeenskap vir huis-en-skoolkonneksies. Hierdie vier hooftemas en subtemas wat uit die versamelde data geïdentifiseer is, word vervolgens beskryf.

\section{TEMA 1: ALGEMENE VERSORGING AS VEREISTE VIR SKOOLBETROKKENHEID}

Die deelnemers se subjektiewe verstaan of persepsies van hul primêre versorgers se betrokkenheid by hul skoolomgewing word eerstens gekenmerk deur die belewing van "ons is mos familie". Hierdie verstaan van "familie" as ouerskap en betrokkenheid word gemeet aan die voorsiening van vroeë adolessente se daaglikse behoeftes, soos kos, water, sanitasie, dak-oor-die-kop en klere. Hierdie bevinding is op die volgende manier verwoord:

D12: “Nou bly hy (pa) anderkant, as ek na hom toe gaan dan jaag hy my weg van sy huis af so juffrou, hy stuur nie vir my geld nie juffrou en al daai goed, ek is nie so much oor hom nie."

Hierdie basiese versorging is ook deel van Maslow se hiërargiese model van basiese behoeftes vir die mens (Maslow, 1968). Al die deelnemers het genoem dat die behoort aan 'n gesin baie belangrik is en dat hierdie familie gesien word as die ruimte waar hulle versorging verwag (Felner, 2006:128). Die belewing van armoede en gebrek behels in sommige huishoudings dat die basiese behoeftes soos kos eers voorsien word, voordat ander nodige items soos skoolskoene oorweeg word. Hierdie belewing van gebrek is op 'n sobere manier verwoord op die volgende manier:

D8 "Daar is miskien nie altyd iets vir ons by die huis om te eet of so nie, aunty. Ons eet miskien in die oggend voor ek skool toe kom, dan drink ek 'n koppie tee. En bietjie pap as daar is. En as ek uit die skool uit kom, brood as daar is aunty".

Die kwessie van die primêre versorgers en werkloosheid oftewel die vraagstuk van ekonomiese onaktiwiteit speel 'n groot rol met betrekking tot die kwaliteit van die algemene versorging wat die deelnemers ondervind. Die betaling van skoolfonds is ' $n$ belangrike kwessie vir die leerders. Die skoolfonds by die betrokke skool is ' $\mathrm{n}$ geringe bedrag van R150.00 per jaar 
en tog is die skoolfonds deur die meeste primêre versorgers nie betaal nie. Slegs drie van die twaalf deelnemers se skoolfonds is betaal tydens die doen van die navorsing. Die deelnemers het wel sonder huiwering vertel wie verantwoordelik is vir die betaal van die skoolfonds. Die deelnemers hanteer hul primêre versorgers se ontwyking van verantwoordelikheid met ' $n$ gelatenheid wat vergelyk kan word met aangeleerde hulploosheid:

D2 "My ma en pa werk nie, maar my ma werk nou en dan en dan werk sy dan. Want my pa werk nie vandat hy uit die dinges gekom het...uit die tronk uit gekom het nie."

Die deelnemers se persepsies van hul primêre versorgers se betrokkenheid by hul skoolomgewing word eerstens gekenmerk deur die verstaan dat 'n familie behoort te voorsien in hul kinders se alledaagse behoeftes. Indien hierdie versorging grootliks ontbreek, word vroeë adolesente erg gekniehalter om die leer-omgewing se verpligtinge en skooltake baas te raak. Daar is vele risikofaktore wat hierdie daaglikse sorg beïnvloed soos die primêre versorgers se armoedige omstandighede wat weer vererger word deur probleemkwessies soos werkloosheid.

\section{TEMA 2: EMOSIONELE AARD VAN HUIS-EN- SKOOL-INTERAKSIES}

Die resultate het aangedui dat die emosionele belewing van die deelnemers se interaksie by die huis-en-skoolkonteks hoofsaaklik negatief gekleur is. Selfs sogenaamde goeie ervarings soos die verstaan van gesinsharmonie is hoofsaaklik weergegee as die afwesigheid van negatiewe gebeure, naamlik as die afwesigheid van gesinsgeweld en rusie. Die belewing van negatiewe emosies soos voortdurende vrees om moeilikheid te vermy of ten beste die slegte ervarings goed te hanteer, word meestal gekenmerk deur bangheid vir "skel" en lyfstraf. Deelnemers se belewing en hantering van negatiewe emosies soos aggressie is hoofsaaklik reaktief:

D11 "As my ma-hulle my skel juffrou en ek raak nou kwaad, ek loop net weg."

Die belewing van veiligheid en aanvaarding wat kenmerkend is van gesonde menslike interaksie (Fredrickson 2013:185) is deur die deelnemers weergegee as die handhawing van emosies wat bloot mindere vrees behels. Alhoewel die deelnemers wel na emosionele ondersteuning van hul primêre versorgers en opvoeders hunker en selfs op bykans idealistiese en oordrewe maniere dit verwoord (byvoorbeeld binne die raamwerk van die visuele materiaal soos in die collages uitgebeeld), is hul belewing van hoofsaaklik negatiewe emosies alledaags.

Die deelnemers se verstaan van hul primêre versorgers se emosionele ondersteuning rakende skool is hoofsaaklik wanneer daar negatiewe gebeure by die skool is. Die primêre versorgers gaan skool toe wanneer die skoolhoof hulle kontak met inligting soos skool-tuiswerk wat herhaalde kere nie gedoen is nie, of dat die deelnemers substansies soos dagga by die skool gebruik.
D2 "Ons het gaan bunk by hulle huis en dinge dan bly ons uit. Dan roep die hoof ma in".

\section{Trooswoorde}

Die deelnemers beleef soms die weelde van positiewe emosionele ondersteuning, byvoorbeeld wanneer hulle by die skool in 'n bakleiery betrokke was:

D4 "Dan sal hulle (ouma en tante) vir my sê ek moenie hartseer is nie of ek moenie ongelukkig is nie. Hulle sal my vashou."

\section{Gebrek aan emosionele ondersteuning}

Verskeie deelnemers beleef emosionele ondersteuning oor skoolsake op 'n uiters gebrekkige manier:

D11 “Nie met my nie, met my pa, want as ek nou vir my pa sê ek wil met my pa...daddy ek wil gou vir daddy iets sê, dan gaan my pa nou sommer beginne skel vir my want hy weet ek het iets sleg gedoen by die skool."

Die dissiplineringstyl van die meeste primêre versorgers behels lyfstraf en voortdurende dreigemente in 'n poging om die deelnemers te leer om hul skoolverantwoordelikhede na te kom. In dié opsig bevestig die primêre versorgers die skool se gesag, maar dit blyk dat hierdie manier van dissiplinering meer aggressie by die deelnemers wek en hulle gebruik dan ook self geweld om moeilikhede te hanteer:

D10 "As almal my so kwaad maak dan wil ek net vir hulle slaan...... Soos hulle praat van my ma wat oorlede is en dan raak ek gou kwaad, daai's die ding. Want hulle moenie saam met my praat van daai nie."

Die hoofsaaklik negatiewe emosionele belewings in die huisen-skoolkonteks rakende skoolsake behels die aggressiewe emosionele response van primêre versorgers, en hierdie reaktiewe gedrag van die volwassenes, word vele kere deur die vroeë adolessente nageboots. Die verskillende vlakke vanintensiteitvannegatieweemosieswisselvanafdievermyding van negatiewe emosies soos teleurstelling en irritasie tot erge woede wat kenmerkend is van die meeste primêre versorgers se dissiplineringstyl. Dit beteken dat negatiewe emosies soos vrees doelbewus gebruik word om vroeë adolessente se gedrag te verander. Selfs die skaars voorkom van positiewe emosionele ondersteuning is verduidelik as die troos om "moeilikheid" te oorkom.

\section{TEMA 3: DIE AARD VAN DIE PRIMÊRE VERSORGER(S) SE BETROKKENHEID BY DIE SKOOLGEMEENSKAP}

Dit blyk dat die deelnemers se primêre versorgers skoolbesoek nie positief beleef of met goeie sake geassosieer nie. Volgens die deelnemers word die primêre versorgers deur die skoolpersoneel gekontak om die skool te besoek om hoofsaaklik slegte sake te hanteer. Die primêre versorgers of ' $n$ familielid sal wel die skool besoek wanneer die kind in die moeilikheid is, soos met bakleiery: 
D8 “Toe kom sy (Ouma) skool toe, sy't nie my part gevat nie, sy't gesê ek moenie daai doen nie, ek moet nooit my hande lig vir'n meisie nie."

Dit blyk dat die sin van behoort tog die negatiewe belewing temper, danksy die feit dat daar wel iemand is wat die deelnemers by die skoolomgewing as familie kan verteenwoordig. Dit is egter nie ongewoon dat ' $n$ familielid in die plek van die primêre versorger die skoolvergaderings bywoon nie, byvoorbeeld ' $n$ tante woon die skoolvergaderings by wanneer die vroeë adolessent se grootouers die primêre versorgers is. Dit blyk dat wanneer die vroeë adolessente se primêre versorgers nie by die skoolgemeenskap betrokke is nie, 'n ander lid van die uitgebreide familie wel die belangrike taak waarneem.

D4 "My broer gaan meetings toe by die skool. My aunty kan nie kom nie want sy's sieklik".

Verder blyk dit dat die deelnemers hoofsaaklik hul primêre versorgers se persepsies van studie en skoolsukses reflekteer. Hierdie verstaan van skoolsukses is beperk tot kategorieë van slaag of druip, en die herhaling van grade word nie as ongewoon geag nie. Hierdie maatstawwe van skoolsukses beïnvloed ook die deelnemers se bykans onrealistiese verwagtings van hul toekomsplanne: Die collages beeld uit dat die deelnemers wel drome koester, byvoorbeeld om eendag te werk as 'n mediese dokter of ' $n$ prokureur, maar hulle beskik nie oor die nodige inligting wat die verwerkliking van hierdie ideale behels nie. nodig is nie. Dit blyk dat die deelnemers se vae toekomsperspektief en toekomsdrome nie ooreenstem met hulle skoolprestasie nie. Sekere deelnemers huiwer nie om gereeld sekere dae nie skool by te woon of klasse en take te ontduik nie:

D9 “Omdat juffrou ekke, ek gee nie al my werk in nie juffrou, is soos my juffrou miskien vir ons werk gegee het juffrou en dan vergeet ek... sê maar my juffrou gee my soos 'n taak juffrou dan moet ons dit huis toe vat juffrou dan vergeet ek om dit te doen juffrou."

Dit is vir die deelnemers ongewoon dat hul ouers doelgerig planne maak sodat hul skoolprestasie kan verbeter en uitsiglose toekomsdrome en vae, of onrealisitiese toekomsdrome, is normaal. Sommige deelnemers se primêre versorgers handhaaf 'n mate van toesig rakende skooltuiswerktake:

D6 "Maar dis my tweede jaar in graad ses. Sy (ma) help my met my wiskunde ook en om hoe ek, om die getalle uit te werk en daai goed, tipe goed."

Dieprimêreversorger(s)of'nanderlidvan dieuitgebreidefamilie sal gewoonlik die vroeë adolessent by die skoolgemeenskap verteenwoordig met ouer-aangeleenthede. Die aard van die primêre versorger(s) se kontak met die skoolgemeenskap is egter hoofsaaklik die hantering van slegte sake waarby die leerders as vroeë adolessente betrokke was, soos slegte gedrag wat bakleiery of swak skoolgedrag soos gereelde afwesigheid insluit. Dit blyk dat sommige primêre versorgers wel in 'n mate toesien dat skoolwerktake gedoen word, veral om verdere herhaling van grade te voorkom.

\section{TEMA 4: DEELNEMERS SE BELEWENISSE VAN 'N HOË-RISIKO OMGEWING}

Al die deelnemers woon in die Delft-omgewing in die Kaapse Skiereiland. Hierdie gemeenskap is amptelik verklaar as een van Suid-Afrika se hoë-risiko omgewings. Al die deelnemers ken die belewings van onveiligheid en was reeds getuies van traumatiese ervarings van geweld:

D1 "Oraait juffrou, maar dis 'n bietjie evil hier juffrou, skiet in die aande, rob die mense, steek mekaar met meste."

Hierdie blootstelling aan geweld in die Delft-gemeenskap is nie bloot stories vir die deelnemers nie, want die belewings van geweld en aggressiewe bakleiery is deel van hul persoonlike leefstories:

D10 “Nie so lekker nie...Die guns skietery, hulle't my brother, vir my broer gesteek deur die longe. Hy was in dink twenty, daar in twenties."

En al die deelnemers het reeds gesien hoe ' $n$ persoon vermoor word, of is geraak deur die afsterwe van familielede as gevolg van gewelddadige aanvalle:

D3 "My nefie, my een nefie was deur die been geskiet toe kom die bullet hier by sy enkel uit toe stuck die bullet en toe swell die so op...en my ander nefie was um 'n paar dae voor ou Christmas geskiet en toe ou Christmas begrawe ons hom."

Die hoë voorkoms van bendes en bendegeweld is bekende gebeure vir die deelnemers:

D8 "My uncle is betrokke in gangsterism. Hy het al iemand doodgemaak al. Toe gat hy tronk toe." D12 "Ja juffrou, want die klein kindertjies word ook geskiet hier en die mense word uitgebrand met tyres en goed."

Naas die gevare van geweld, behels die leefstyl van die bendes ook groot risiko's, aangesien kinders en die deelnemers as vroeë adolessente aan substanse, alkohol en dagga bekendgestel word:

D11 "Is nie eintlik lekker nie, want jy sien baie keer hoe hulle mense doodmaak en mense wat dwelms gebruik, somtyds is dit sommer meisiekinders wat jonk is, dan gebruik hulle tik en al daai goeters."

Deelnemers is op ' $n$ eerlike manier bewus van die implikasies van die destruktiewe gedrag soos hulle dit beleef as die kinders van die gemeenskap, en dat byvoorbeeld die bendelewe vir vele vroeë adolessente 'n alternatief bied om te oorleef.

Die deelnemers het ook hul gemeenskap beskryf in terme van erge armoede:

D2 "Dis nie mooi om te sien hoe lyk die plek nie. Um... die kinders, sommige van die kinders is honger en dan slaap hulle buite, hulle het nie klere nie, hulle word siek van die kouete, ja en hulle's hartseer." 
Hierdie belewings van die hoë-risiko omgewing kan opgesom word as ' $n$ integrale deel van vroeë adolessente se persoonlike leefstories. Hul ervarings behels die voortdurende werklikheid van gevare en onveiligheid, traumatiese ervarings van geweld wat hul familie sowel as vriende reeds deurleef het. Hierdie volgehoue blootstelling aan destruktiewe gedrag soos bende-gedrag asook hul familie-lede se substansie-misbruik beklemtoon die "geweld" van armoede waarvan hul as vroeë adolessente eerste-rangse getuies is.

Die deelnemers se persepsies van hul primêre versorgers se betrokkenheid by hul skoolomgewing word eerstens gekenmerk deur die verstaan dat ' $n$ familie behoort te voorsien in hul kinders se daaglikse behoeftes. Die teenwoordigheid van vele risikofaktore behels dat hierdie basiese versorging vroeë adolesente se skoolsukses ernstig belemmer. ' $n$ Tweede aspek is die hoofsaaklik negatiewe aard van emosionele belewings in die huis-en-skoolkonteks rakende skoolsake. Vroeë adolessente se persepsies dui op grade van negatiwiteit wat wissel van die vermyding van negatiewe emosies tot primêre versorgers se doelbewuste gebruik van negatiewe emosies om vroeë adolessente te dissiplineer. ' $\mathrm{n}$ Derde aspek het te make met die spesifieke aard van primêre versorgers se kontak met die skoolkonteks wat gekenmerk word deur hoofsaaklik die hantering van slegte sake waarby die leerders as vroeë adolessente betrokke was, soos slegte gedrag en bakleiery, of swak skoolgedrag as gereelde afwesigheid. Dit blyk dat sommige primêre versorgers wel in 'n mate toesien dat skoolwerktake gedoen word, veral om verdere herhaling van grade te voorkom. Die laaste aspek is vroeë adolessente se belewings van die hoë-risiko gemeenskap wat hul grootword-plek is, en hul persepsies van huis-en-skool as primêre sosialiseringsagente, huisves. Hierdie vier temas word vervolgens kortliks bespreek.

\section{BESPREKING}

Die hooftemas wat op ' $\mathrm{n}$ induktiewe wyse ge-identifiseer is, beskryf vroeë adolessente se persepsies van hul primêre versorgers se betrokkenheid by die skoolgemeenskap in 'n hoë-risiko omgewing. Primêre versorgers word deur die vroeë adolessente beskou as die verteenwoordigers van die familie wat verantwoordelik is vir hul algemene versorging en veiligheid. Die bevindings toon dat wanneer die primêre versorger(s) grootliks nie in hierdie daaglikse behoeftes voorsien nie, dit negatiewe gevolge inhou vir vroeë adolessente se skoolervarings en skoolsukses.

Die deelnemers se persepsies van hul pimêre versorgers se betrokkenheid by die skoolomgeweing is hoofsaaklik negatief gekleur, omdat die redes vir skoolbesoeke meestal te vind is daarin dat die skoolhoof die versorgers ontbied om krisisgebeure rakende hul kinders te hanteer. Hierdie negatiwiteit beteken dat die belewing van negatiewe emosies verreweg die positiewe emosies oorheers wanneer beide die primêre versorgers en vroeë adolessente se vrese om te oorleef akkumuleer as gevolg van moontlike skoolprobleme. Die vroeë adolessente se responsiewe negatiwiteit (Fredrickson 2013) behels laer vlakke van psigologiese, sosiale en emosionele gesondheid (Van Schalkwyk \& Wissing 2010: 57). Aan die anderkant kan die meerdere belewing van positiewe emosies soos liefdevolle troos wat hulle beleef wanneer hul primêre versorger(s) hulle bemoedig met skoolwerk of slegte skoolervarings, lei tot verbeterde prestasievermoë en algemene gesondheid.

Die aard van die primêre versorgers se betrokkenheid by die skoolgemeenskap is aangedui as skoolbesoeke wat gemik is op die hantering van hul kinders se risikogedrag, soos leerders wat dagga gebruik of herhaaldelik versuim om skooltuiswerk te doen. Louw, Bayat en Eigelaar-Meets (2011:1-74) meld dat primêre versorgers se lae vlakke van skoolopleiding of ongeletterheid 'n moontlike faktor is wat kan bydra tot gebrekkige ondersteuning, aangesien die primêre versorgers nie die waarde van skool-opvoeding hoog ag nie. Agt van die twaalf deelnemers aan hierdie navorsing het reeds skoolgrade herhaal. Hierdie navorsingsbevindings bevestig vorige navorsing wat daarop dui dat primêre versorgers se onvoldoende betrokkenheid by die skoolomgewing 'n bydraende faktor is tot leerders se volgehoue swak skoolervarings, swak skoolbywoning en hoë herhaalsyfers (Louw, Bayat, \& Eigelaar-Meets 2011:1-74). Hierdie onvoldoende betrokkenheid van primêre versorgers dui op faktore soos swak toesig rakende skooltake, en min belangstelling of pogings om vroeë adolessente se skoolprestasie daadwerklik te bevorder.

Dit blyk dat vroeë adolessente hul primêre versorgers se persepsies van skoolsukses, naamlik die slaag van 'n skoolgraad of nie, as aanduider van skoolsukses in 'n groot mate reflekteer. Verder toon die bevindings dat die vroeë adolessente met gelatenheid aanvaar dat 'n ander familielid skoolbesoeke waarneem indien primêre versorgers dit vermy. Verder is dit ook duidelik dat die verstaan van ouers en familie as primêre sosialiseringsagente hoofsaaklik kultureel bepaal word.

Die deelnemers se verstaan van die hoë-risiko omgewing bevestig vorige studies se bevindings (Felner 2006; Nelson \& Prilleltensky 2010; Ungar 2011) wat dui op die interaktiewe en dinamiese aard van die individu én die omgewing. Hierdie direkte leefkontak met die hoë-risiko gemeenskap is verwoord deur die deelnemers as persoonlike traumatiese belewings wat vele vorms van misdaad en geweld insluit soos moord, bende-geweld, die gebruik van onwettige substansies deur ouers en kinders, en die daaglikse blootstelling aan'n onveilige leefwêreld. Die vroeë adolessente se persepsies van hul primêre versorgers se betrokkenheid by die leeromgewing moet gesien word binne die konteks van 'n hoë-risiko omgewing wat veel meer behels as gevare en voortdurendevrese. Die huis-en-skoolkonteks verteenwoordig vroeë adolessente, ' $n$ belangrike leef-fase, se ruimte van fisiese en psigologiese ontwikkeling. Bestaande teorieë soos Bronfenbrenner se bio-ekologiese model (Rosa \& Tudge 2013:243-258) toon die besliste wederkerige invloed van omgewing en persoon rakende die kind se ontwikkeling. Hierdie oorhoofse prentjie is egter donker wanneer vroeë adolessente hul primêre versorgers (wat hoofsaaklik nie hul biologiese ouers verteenwoordig nie) se betrokkenheid by die skoolgemeenskap beskou as die gebrekkige voorsiening in alledaagse behoeftes, terwyl die hoofsaaklik negatiewe emosionele aard van skool-en-huis interaksies voordurend versleg, aangesien primêre versorgers se negatiewe belewing van die 
leer-omgewing weer verdere negatiewe patrone ontlok wat geassosieer word met ' $n$ hoë-risiko omgewing.

\section{KONKLUSIE}

Primêre versorgers is belangrike welstandsvennote van vroeë adolessente. Hierdie versorgers se interaktiewe verhoudingskonneksies met die skoolkonteks in 'n hoërisiko omgewing is van beslissende belang vir vroeë adolessente se persoonlike welstand en skoolsukses. Alhoewel gesonde verhoudingsbetrekkinge tussen huis-en-skool 'n ryke belegging in die huidige en toekomstige welstand van vroeë adolessente kan bied, toon die bevindings van hierdie studie dat risiko's rakende oorlewingskwessies inderdaad die verhoudingskwaliteite tussen vroeë adolessente se primêre sosialiseringsagente belemmer. Hierdie afwesigheid van gesonde betrokkenheid kan bydra tot die belewing van lae vlakke van psigologiese, emosionele en sosiale welstand vir vroeë adolessente (Van Schalkwyk \& Wissing 2010:57). Die gebrekkige voorkoms van omvattende welstand vir vroeë adolessente impliseer die groter moontlikhede van weerloosheid en risiko-gedrag soos gebrekkige selfregulering en substansie-gebruik; seksueel-riskante gedrag en tienerswangerskappe; asook swak skool-prestasie en die moontlikhede van skool-uitval ("drop-out").

Alhoewel navorsers maan dat verhoudingsfunksies in die lig van interpersoonlike kontekste asook die interaktiewe aard van die individu se verhouding met ander én die omgewing, bestudeer moet word, sou die positiewe benadering van die sielkunde blind wees indien welstand bedink word sonder die inagneming van sosiale geregtigheid ("social juctice") (Prilleltensky 2012:1). Hierdie studie bevestig dat welstand beslis meer as die blote afwesigheid van siekte-toestande vir individue, verhoudings, groepe en gemeenskappe behels. Dit beteken ook die dinamiese teenwoordigheid van daardie faktorewatobjektiewebehoeftes, (materiëleen fisiese behoeftes) asook subjektiewe behoeftes (emosionele en psigologiese faktore) van individue, verhoudings, groepe en gemeenskappe bewerk en handhaaf (Diener et al. 2010:3-15; Keyes 2007:95; Veenhoven 2007). Gandhi het opgemerk dat armoede die wreedste vorm van geweld is wat kinders kan ondervind, en in hierdie opsig blyk dit dat vroeë adolessente se belewing van hul primêre versorgers se betrokkenheid by die leeromgewing ' $n$ illustrasie is van gefaalde sosiale geregtigheid. Dit is juis die kombinasie van al hierdie genoemde faktore wat 'n rol speel om skool- en leefsukses te bewerkstellig. 'n Beskrywing van welstand wat hierdie kombinasie van faktore in ag neem, bied meer as blote mediese en psigologiese definisies van menslike bestaan.

Alhoewel vele Suid-Afrikaanse vroeë adolessente die waarde van behoort-aan-'n-familie en verhoudingswelstand besef, blyk dit dat vroeë adolessente se persepsies van hul versorgers se betrokkenheid by die leeromgewing ten onregte geraak word deur die armoede-geweld van hul hoë-risiko gemeenskap.

Aanbevelings vir verdere studie is die ontwikkeling van geskikte intervensies vir primêre versorgers en vroeë adolessente in hoë-risiko-omgewings wat die hulpbronne van die breër gemeenskap asook adolessente se innerlike sterktes toenemend ontgin en ontwikkel. Die eksterne faktore behels die ondersteuning van primêre versorgers in die huisen-skoolkonteks, en die innerlike sterktes verwys na daardie toewyding aan hul studies, positiewe identiteit, en, 'n positiewe ingesteldheid rakende hul toekoms. 


\section{VERWYSINGS}

Braun, V., \& Clarke, V., 2006, Using thematic analysis in psychology, Qualitative Research in Psychology, 3:77-101.

Brooks, R.B., 2006, 'The power of parenting', in S. Goldstein \& R.B. Brooks (ed.), Resilience in children, Springer, New York.

Strategic Development information Department, city of Cape Town. 2011. Census 2011. City of Cape Town - 2011 Census - Ward 106 https://www.capetown.gov. za/en/stats/Documents/2011\%20Census/Wards/2011_Census_CT_Ward_106_ Profile.pdf. [28 October, 2013]

Census, 2011.

https://www.capetown.gov.za/en/stats/Documents/2011\%20Census/Wards/2011_ Census_CT_Ward_106_Profile.pdf. Date of access: 28 October, 2013

Gries, H.B. 1996. Experimental learning. Education online, 21(1). http://www.edu. learning.html [14 Oktober 2004].

Creswell, J.W., 2007, Qualitative Inquiry and Research Design: Choosing among Five Approaches, Sage Publications, London.

Diener, E., Kahneman, D., tov, W., \& Arora, R., 2010, 'Income's association with judgments of life versus feelings', in E. Diner, J. Helliwell, \& D. Kahnemam (eds.), International differences in well-being (pp. 3-15),Oxford University Press, New York.

Ellingson, L.L., 2009, Engaging crystallization in qualitative research : An introduction, SAGE Publications Ltd., Thousand Oaks, CA.

Felner, R.D., 2006, 'Poverty in childhood and adolescence, in Goldstein and Brooks (eds.), Resilience in children. Springer, New York.

Fredrickson, B. L., 2009, Positivity, Three Rivers Press, New York.

Fredrickson, B.L., 2013, 'Updated Thinking on Positivity Ratios' American Psychologist [Advance online publication]. Doi: 10.1037/a0033584

Gouws, A., 2015, “Going it alone: When citizens can't trust the state,” Winterskool, Teologiese Fakulteit, Stellenbosch Universiteit.

Hong, S., \& Ho, H.-Z., 2005, 'Direct and indirect longitudinal effects of parental involvement on student achievement: Second order latent growth modeling across ethnic groups', Journal of Educational Psychology, 97(1):32-42.

Hope, J. \& van der Merwe, M., 2013, 'An intergenerational perspective on risk and protective factors in multi-problem poor families living in Cape Town', Social Work/Maatskaplike Werk, 49(3):309-331)

Jaffee, S.R., 2006, 'Family violence and parent psychopathology',in S. Goldstein \& R.B. Brooks (eds.), Resilience in children, Springer, New York.

Jodl, K.M. Michael, A. Manlanchuk, O. Eccles, J.S. \& Sameroff, A. July/August, 2001, 'Parents' roles in shaping early adolescents' occupational aspirations', Child development, 72, 1247-1265.

Keyes, C.L.M., 2005, 'Mental illness and/or mental health? Investigating axioms of the complete state model of health', Journal of consulting and clinical psychology, 73 (3):539-548.

Keyes, C.L.M., 2007, 'Promoting and protecting mental health as flourishing', American psychologist, 62 (2):95-108.

Keyes, C.L.M., 2009, 'The nature and importance of positive mental health in America's adolescents' in Gilman, Huebner \& Furlong (ed.), Handbook of Positive Psychology in schools, Routledge, New York.

Kitching, A., Roos, V., \& Ferreira, R., 2012, 'Towards an understanding nurturing and restraining relational patterns in school communities', Journal of psychology in Africa, 22 (2):39-51
Khumalo, I. P., Temane, Q. M., \& WISSING, M.P., 2012, 'Socio-Demographic Variables, General Psychological Well-Being and the Mental Health Continuum in an African Context', Social Indicators Research, 105(3), 419-442. doi:10.1007/ s11205-010-9777-2

Louw, W., Bayat, A. \& Eigelaar-Meets, I.,2011,. 'A report of underperforming secondary schools in the Western Cape', Institute of Social Development. University of the Western Cape, Bellville.

Louw, D.A. Van Ede, D.M. Louw, E.A., 2001, Menslike ontwikkeling, Derde uitgawe, Kagiso, Kaapstad.

Malgarte, C.R., 2013, Persoonlike onderhoud: Skoolhoof.

Maslow, A.H., 1968, Toward a psychology of being, Van Nostrand, Princeton.

Nelson, G., \& Prilleltensky, I., 2010, Community psychology, in pursuit of liberation and well-being, 2de uitgawe, Palgrave Macmillan, New York.

Pityana, B., 2015, "Call to discipleship - Where is the Church of God?" Winterskool Teologiese Fakulteit, Stellenbosch Universiteit.

Prilleltensky, I., 2005, 'Promoting well-being: Time for a paradigm shift in health and human services', Scandinavian journal of public health, 33 (66) :53-60

Prilleltensky, I., 2012, Wellness as fairness. American Journal of Community Psychology, 49(1-2), 1-21. doi:10.1007/s10464-011-9448-8

Republiek Van Suid-afrika. 1996. Suid-Afrikaanse Skolewet Wet 84 van 1996. Pretoria: Staatsdrukkery

Reschley, A.L. \& Christenson, L.S., 2009, 'Parents as essential partners for fostering students' learning outcomes', in R. Gilham, E.S. Huebner \& M.J. Furlong (eds.), Handbook of Positive Psychology in schools, Routledge, New York.

Rosa, E. M., \& Tudge, J., 2013, 'Urie Bronfenbrenner's Theory of Human Development: Its Evolution From Ecology to Bioecology', Journal of Family Theory \& Review, 5(4), 243-258. doi:10.1111/jftr.12022

Seligman, M.E.P., 2011, Flourish, Simon \& Schuster Inc., New York.

Strydom, H., 2011, 'Ethical aspects of research in the social sciences and human service professions' in De Vos, A.S., Strydom, H. Fouche, C.B. \& Fouche, C.S.L. Delport (eds.), Research at Grass Roots: For the social sciences and human service professions (4th edition), Van Schaik, Pretoria.

Tomyn, A.J. \& Cummins, R.A., 2010, 'The Subjective Well-being of High-School Students: Validating the Personal Well-being Index' School Children School of Psychology, Deakin University, Burwood, VIC, Australia e-mail: robert. cummins@deakin.edu.au

Tracy, S.J., 2010, 'Qualitative Quality: Eight “Big-Tent” criteria for excellent research', Qualitatve Inquiry, 16(1):837-851.

Ungar, M., 2008, 'Resilience across cultures', British Journal of Social Work, 38, 218-235.

Ungar, M., 2011, Counseling in challenging contexts: Working with individuals and families across clinical and community settings, Brooks/Cole, Belmont, CA.

Ungar, M., \& Teram, E., 2000, 'Drifting toward mental health. High risk adolescents and the process of empowerment, Youth and society, 32 (2):228-252.

Van Schalkwyk, I., \& Wissing, M.P., 2010, 'Psychosocial well-being in a group of South African adolescents', Journal of Psychology in Africa, 20(1):53-60.

Van Schalkwyk, I. \& Wissing, M.P., 2013, 'Evaluation of a programme to enhance flourishing in adolescents', in Wissing (ed.), Well-being research in South Africa, Springer, Dordrecht.

Veenhoven, R., 2007, 'Subjective measures of well-being',in M.McGillivray (ed.), Human well-being: Concept and measurement, Palgrave Macmillan, New York. 